地域在住高齢者の転倒経験と EC-FRT との関係

\title{
Relationships between fall experiences and the functional reach test with eyes closed (EC-FRT) in local elderly residents
}

\author{
大田尾 浩 ${ }^{1)}$ 上城 憲司 ${ }^{1)}$ 八谷 瑞紀 ${ }^{1)}$ 村田 伸 ${ }^{2)}$ \\ 高島 恵 ${ }^{1)}$ 夏秋 佳奈 $^{11}$ 溝田 勝彦 ${ }^{1)}$ \\ Hiroshi OtaO'), Kenji Kamijou'1), Mizuki Hachiya1), Shin Murata ${ }^{2)}$, \\ Megumi Takashima ${ }^{1)}$, Kana Natsuaki ${ }^{1}$, Katsuhiko Mizota ${ }^{1)}$ \\ 要旨：[目的］EC-FRT（functional reach test with eyes closed）から地域在住高齢者の \\ 転倒の有無を判別できるのかを検証した。[対象］介護認定を受けていない地域在住高齢 \\ 者101名とした。［方法］EC-FRT，FRT および過去 1 年間の転倒歴を測定した。［結果］ \\ EC-FRT は，加齢とともに低下していた。また，EC-FRTは非転倒群よりも転倒群の方 \\ が低值であった。とくに，EC-FRT が25.5cm 以下になると転倒リスクが高くなっていた。 \\ EC-FRTは「転倒あり」の判別よりも「転倒なし」の判別の方が診断精度は高く, FRT \\ よりも EC-FRTの方がより正確に転倒を判別できた。[結語］高齢者が転ばないように， \\ 目指すべき立位バランスの目標值を EC-FRT から設定できる可能性が示された。 \\ キーワード：地域在住高齢者, 転倒, 閉眼での FRT
}

\begin{abstract}
Purpose] Investigate whether the purpose of this study can distinguish fall by EC-FRT (the functional reach test with eyes closed) [Subjects] Subjects were 101 local elderly residents who are not certified as being in need of care. [Methods] The EC-FRT and FRT scores were measured, and the history of falls in the past year was investigated. [Results] The EC-FRT score decreased with age. It was also lower in a group with than without fall experiences. The risk of falls was higher when the EC-FRT score was below 25.5 $\mathrm{cm}$. EC-FRT showed a higher accuracy for identifying subjects without than with fall experiences. The accuracy of identifying the presence or absence of falls was higher with EC-FRT than FRT. [Conclusion] The results suggest that EC-FRT may be useful for setting a target of standing balance.
\end{abstract}

Key words: local elderly residents, fall, functional reach test with eyes closed

\footnotetext{
受付日：2014年 6 月23日，採択日：2014年 7 月28日

1) 西九州大学リハビリテーション学部

干842-8585 佐賀県神埼市神埼町尾崎4490- 9

E-mail : ootaohi@nisikyu-u.ac.jp

Faculty of Rehabilitation Sciences, Nishikyushu University

4490-9 Ozaki, Kanzaki, Saga, 842-8585, Japan.

2) 京都滳大学健康科学部

Faculty of Health Sciences, Kyoto Tachibana University
} 


\section{I 、はじめに}

Functional reach test（FRT）は，高齢者の転倒予 測に有用とされる立位バランス能力の評価法である1)。 だが，FRTのみでは転倒を十分に予測できないと指 摘されている ${ }^{2)}$ 。そこで, 従来のFRTに修正を加え た閉眼にて行う FRT (functional reach test with eyes closed:EC-FRT) が考案されだ”。EC-FRTは, Berg balance scale や Timed up and go test との関連から FRTよりもバランス能力をより反映するとされてい る3゙。また，EC-FRTの信頼性は高く測定誤差は少な いことが確認されている゙)。しかしながら， EC-FRT の有用性の確認は十分になされているとは言えない。 臨床で利用できる評価法は, その測定值から臨床的意 義を解釈できる必要がある。そこで本研究は, 地域在 住高齢者を対象に EC-FRT から転倒の有無を判別で きるのかを検証した。

\section{II. 対象と方法}

\section{1. 対 象}

対象は，認知症予防推進事業に自由意志で参加した 65歳以上の地域在住高齢者101名（平均年齢76.6 06.0 歳, 男性22名, 女性79名）とした（表 1 ）。対象の取 り込み基準は, 研究の参加に同意が得られ, 要介護認 定を受けておらず，麻痺などの明らかな神経症状がな い者とした。対象者は, 調査の実施会場である公民館 へ自ら来場できる程度に自立していた。なお, MMSE (mini-mental state examination) が20点以下で医師 から認知症と診断を受けた者は対象から除外した。

対象者には，事前に研究の趣旨と内容を十分に説明 し, 研究参加の同意書にサインを得たうえで研究を開 始した。研究の参加は自由意思であり, 調査に協力を せずに途中で中止した場合であっても対象者には不利 益を生じないことや，計測後においても同意を撤回で きることを説明した。

\begin{tabular}{cc} 
表 1 地域在住高齢者の属性 $(\mathrm{n}=101)$ \\
\hline 年齢（歳） & $76.6 \pm 6.0$ \\
性別 $($ 男性 /女性 $)$ & $22 / 79$ \\
身長 $(\mathrm{cm})$ & $149 \pm 6.7$ \\
$\mathrm{FRT}(\mathrm{cm})$ & $28.2 \pm 9.3$ \\
$\mathrm{EC}-\mathrm{FRT}(\mathrm{cm})$ & $26.9 \pm 9.8$ \\
$\mathrm{MMSE}$ (点) & $26.2 \pm 3.0$ \\
歩行速度 (秒) & $5.8 \pm 2.8$ \\
\hline 平均土標準偏差
\end{tabular}

\section{2. 方 法}

測定項目はEC-FRT, FRT, 過去 1 年間の転倒歴 とした。

FRTおよびEC-FRT は，ファンクショナルリーチ 測定器（竹井機器工業製， T.K.K. 5802）によって 測定した。対象者の歩幅は肩幅程度とし，上肢を前腕 回内・肘関節伸展 ・肩関節 $90^{\circ}$ 屈曲位に保持させた肢 位を測定開始肢位とした。対象者にできる限り前方へ リーチさせた。リーチの際は，対象者に頭部を前屈せ ずに指先を見たまま手が下がらないようにリーチをさ せた。体幹を回旋させたり足部を動かさないように注 意をし，測定開始肢位に戻らせて測定終了とした。計 測は開眼で練習を行った後に，開眼と閉眼を交互に 2 回ずつ測定し最大值 $(\mathrm{cm})$ を採用した。なお，閉眼 での計測時には，検者は対象者のすぐ傍にいて転倒し そうになった場合には素早く転倒を防ぐように十分に 注意した。

転倒歴は聞き取りにより聴取し，転倒経験者を転倒 群，転倒経験のない者を非転倒群とした。転倒経験は, 過去 1 年間の転倒経験の有無を対象者に想起させ回答 を得た。なお，転倒とは「自分の意志からではなく， 地面またはより低い場所に膝や手などが接触する」 ${ }^{5)}$ と した。

統計処理は，各測定項目をShapiro-Wilk 検定によ り正規性を確認した。EC-FRTをKruskal-Wallis 検 定にて年代別に比較した。多重比較法はBonfferoni 法の不等式にて有意確率を補正して比較した。また, EC-FRT と FRT とをWilcoxonの符号付順位検定に て比較した。次に, 転倒群と非転倒群の EC-FRTを Mann-Whitney 検定にて比較した。転倒の有無を判別 するためにROC (receiver operating characteristic) 曲線を求め, AUC (area under the curve) から適合 性を判定しカットオフ值を求めた。カットオフ值は「感 度＋特異度」が最大となる点に設定した。さらに，カッ トオフ值から求められる予測值と実測值から感度，特 異度，正診率などを算出した。統計解析にはSPSS 21

(IBM) を用いた。

\section{III. 結 果}

EC-FRT の中央值（四分位範囲）は，65-69歳35.5 （11.0） cm，70-74歳32.5（7.0） cm，75-79歳26.0 (7.0) cm, 80-84歳24. 0 （14.0） cm, 85-89歳23.0 (30.0） cm であった（表 2$)$ 。高齢になるにつれて EC-FRT は有意に低下していた。また，EC-FRTの 
表 2 年代別参考值

\begin{tabular}{cccccc}
\hline 年代(歳) & $\mathrm{n}$ 数 & 転倒なし(人) & 転倒あり $($ 人) & EC-FRT $(\mathrm{cm})$ & $\mathrm{FRT}(\mathrm{cm})$ \\
\hline $65-69$ & 11 & 11 & 0 & $35.5(11.0)$ & $36.5(11.0)$ \\
$70-74$ & 24 & 20 & 4 & $32.5(7.0)^{*}$ & $35.0(10.0)^{\dagger}$ \\
$75-79$ & 35 & 22 & 13 & $26.0(7.0)^{*}$ & $26.0(10.0)^{\dagger}$ \\
$80-84$ & 17 & 8 & 9 & $24.0(14.0)^{*}$ & $24.0(6.0)$ \\
$85-89$ & 14 & 9 & 5 & $23.0(30.0)^{*}$ & $23.5(28.0)$ \\
\hline 中央值 (四分位範囲) \\
* vs 65-69 p $<0.01,{ }^{\dagger}$ EC-FRT vs FRT $\mathrm{p}<0.05$
\end{tabular}

中央值 (最小值-最大值) は, 非転倒群30.5(27.0-34.0) $\mathrm{cm}$ よりも転倒群20.0（16.0-24.0） cm の方が有意に 低值であった。EC-FRT から求めた ROC 曲線の AUC は, $\mathrm{EC}-\mathrm{FRT}=0.91(95 \% \mathrm{CI}: 0.85-0.97), \mathrm{FRT}=$ 0.86 (0.77-0.94) であった。転倒を判別する EC-FRT のカットオフ值は $25.5 \mathrm{~cm}$ であった。カットオフ值の 感度は $83.9 \%$, 特異度 $85.7 \%$, 正診率 $85.1 \%$, 陽性適 中率 $72.2 \%$ ，陰性適中率92.3\%であった。なお，ECFRT が20. $5 \mathrm{~cm}$ 以下の13名すべてが転倒しており, 33 $\mathrm{cm}$ 以上の29名すべてに転倒はなかった。FRTのカッ トオフ值は $26.5 \mathrm{~cm}$ であった。カットオフ值の感度は $77.4 \%$, 特異度 $80.0 \%$, 正診率 $79.2 \%$, 陽性適中率 $63.2 \%$ ，陰性適中率 $88.8 \%$ であた。なお，FRTが $20.0 \mathrm{~cm}$ 以下の11名すべてが転倒しており, $38 \mathrm{~cm}$ 以 上の 12 名すべてに転倒はなかった（表 3 )。

\section{IV. 考 察}

地域在住高齢者 101 名の過去 1 年間の転倒歷を調查 し，EC-FRTから転倒の有無を判別できるのかを検 証した。その結果, EC-FRT は加齢とともに低下し ており，EC-FRTが $25.5 \mathrm{~cm}$ 以下になると転倒リスク が高くなっていた。EC-FRTは「転倒あり」の判別 よりも「転倒なし」の判別の方が診断精度は高く, FRT よりも EC-FRTの方がより正確に転倒を判別できた。 地域在住高齢者の EC-FRTは, 加齢とともに低下 していた。開眼でのバランス能力は60歳代から急速に 低下し, 閉眼でのバランス能力は40歳代から低下す る6.7)。EC-FRTは，姿勢を制御しながらのリーチ動 作に加えて, 閉眼による視覚の遮断から検查課題の難 易度は高まる。実際に EC-FRT はFRTよりも低值 であった。年代別にみた EC-FRT が加齢とともに次 第に低下していたのは妥当な結果であろう。

EC-FRT から転倒の判別能を検討した。非転倒群 よりも転倒群の方が EC-FRT は低值であった。また, 転倒の判別能を AUC から判断すると, EC-FRT の判
表 3 カットオフ值と転倒の判別精度

\begin{tabular}{|c|c|c|}
\hline & EC-FRT & FRT \\
\hline すべての者が転倒なし（cm） & $\geqq 33.0$ & $\geqq 38.0$ \\
\hline カットオフ值 $(\mathrm{cm})$ & 25.5 & 26.5 \\
\hline すべての者が転倒あり（cm） & $\leqq 20.5$ & $\leqq 20.0$ \\
\hline 転倒率（\%） & \multicolumn{2}{|c|}{30.7} \\
\hline 感 度（\%） & 83.9 & 77.4 \\
\hline 特異度（\%） & 85.7 & 80.0 \\
\hline 正診率（\%） & 85.1 & 79.2 \\
\hline 陽性的中率（\%） & 72.2 & 63.2 \\
\hline 陰性的中率（\%） & 92.3 & 88.8 \\
\hline 陽性尤度比 & 5.9 & 3.9 \\
\hline 陰性尤度比 & 0.4 & 0.3 \\
\hline オッズ比 & 15.6 & 13.7 \\
\hline
\end{tabular}

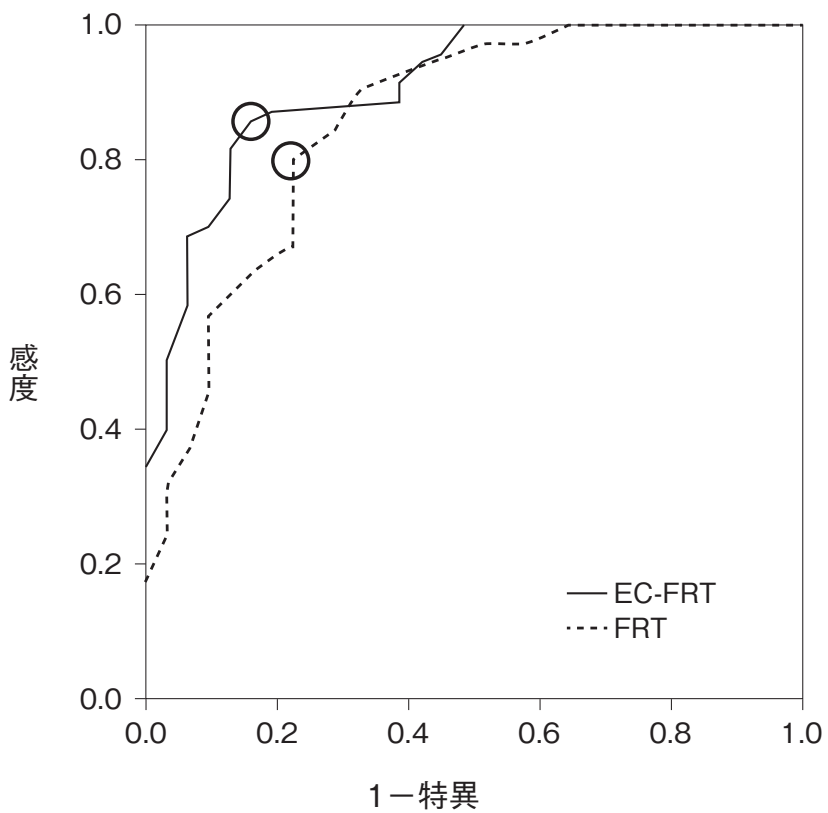

図1 転倒を判別する EC-FRT ならびにFRT の ROC 曲線 EC-FRT の AUCは0.91 (95\%CI : 0. 85-0.97), FRTは0.86 (0.77 -0.94）であった。丸印は，それぞれのカットオフ值を示している。

別能は良好 $(\mathrm{AUC}=0.91$, 高度 $: 0.9-1.0)$ であり, FRT の判別能は中程度 $(\mathrm{AUC}=0.86$, 中等度 : 0.7 0.9)であると判断できた。EC-FRTのカットオフ值 
$25.5 \mathrm{~cm}$ から予測值と実測值から転倒の判別精度を算 出した。陽性的中率が高い検査で「転倒あり」と判定 された場合は転倒の可能性は高く，陰性的中率の高い 検査で「転倒なし」と判定された場合は転倒の可能性 は低いと言える。EC-FRT のカットオフ值を $25.5 \mathrm{~cm}$ に設定した場合，「転倒あり」を判別する精度（陽性 的中率72.2\%) よりも「転倒なし」を判別した精度（陰 性的中率92.3\%）の方が成績は良好であった。このこ とは，EC-FRTは「転倒あり」の判別よりも「転倒 なし」を判別することの方が有用であることを示して いる。また, 転倒の判別精度はFRTよりも EC-FRT の方が良好な值を示しており，EC-FRTを用いた転 倒の判別は有用である可能性が示された。ただし，こ れらの診断精度の值は対象とした集団の転倒率に影響 される。つまり, 対象の転倒率が高い場合, 陽性的中 率が高くなる。本研究の対象者の転倒率は $31 \%$ であっ た。転倒率を報告している先行研究によると， 5 年間 の追跡調査による地域在住高齢者の年間転倒率は, 男 性で20.0\%，女性が20.8\%と報告されている8 。その 他に，大規模集団を対象とした地域在住高齢者の年間 転倒率は, 65 歳以上で $28 \sim 35 \%{ }^{9-11)}$, 75 歳以上では32 $\sim 42 \%{ }^{12,13)}$ と報告されている。本研究の対象者の転倒 率は, 先行研究と同程度であることから, EC-FRT から求めた転倒の判別精度は妥当な成績であると考え られる。Duncan ら¹ は, FRT が15. $3 \mathrm{~cm}$ 未満 $(6$ inch) だと 6 カ月のあいだの転倒率は高いと報告しているが, さらに $25.4 \mathrm{~cm}$ (10 inch) を下回ると次第に転倒のリ スクは高まると指摘している。本研究が示した FRT のカットオフ值 $26.5 \mathrm{~cm}$ と近似していた。

これらの結果から, EC-FRT は高齢者のバランス 能力を捉える指標となり得る可能性が示された。ただ し, 地域在住高齢者に発生する転倒の原因は, バラン 又障害の他に筋力低下や視覚障害, 認知障害, 関節炎 など複数の要因が関与しておりり ${ }^{14)}$, 加えて転倒の危険 を高める要因として環境要因が挙げられている ${ }^{15}$ 。こ のことから, 立位バランス能力のみでの転倒判別を行 うことは注意を要する。さらに, 本研究は後ろ向きに よる過去の転倒経験から転倒の判別能を検討した。過 去 1 年間の転倒経験は将来の転倒予測に強く影響する 要因 ${ }^{16)}$ ではあるが, 縦断研究によりさらに検討するこ とが求められる。

本研究により, 地域在住高齢者を対象とした ECFRTの有用性が確認され, また転倒の判別能が明ら かとなった。EC-FRTは, 地域在住高齢者が転ばな
いために必要な立位バランスの目標值を提示できる可 能性が示された。バランス能力のトレーニングや具体 的な目標值設定などへの応用が期待できる。

\section{引用文献}

1) Duncan PW, Studenski S, Chandler J, et al: Functional reach: predictive validity in a sample of elderly male veterans. J Gerontol, 1992, 47(3): M 93-98.

2) Behrman AL, Light KE, Flynn SM, et al.: Is the functional reach test useful for identifying falls risk among individuals with Parkinson's disease? Arch Phys Med Rehabil, 2002, 83 (4): 538-542.

3 ）大田尾浩, 村田伸, 八谷瑞紀 - 他 : Functional reach test は閉眼の方がバランス能力をより反映する一脳卒中患者に おける検討 - . ヘルスプロモーション理学療法研究, 2013, 3 (1) : $5-9$

4) 大田尾浩, 村田伸, 田中真一・他：地域在住高齢者におけ る閉眼 Functional reach test（EC-FRT）の信頼性と妥当 性. ヘルスプロモーション理学療法研究, 2014, 3 (4) : 157-161.

5 ) Ory MG, Schechtman KB, Miller JP, et al: Frailty and injuries in later life: the FICSIT trials. J Am Geriatr Soc, 1993, 41(3): 283-296.

6 ) Choy NL, Brauer S, Nitz J.: Changes in postural stability in women aged 20 to 80 years. J Gerontol A Biol Sci Med Sci, 2003, 58(6): 525-530.

7 ) Bohannon RW, Larkin PA, Cook AC, et al.: Decrease in timed balance test scores with aging. J.Phys Ther, 1984, 64 (7): 1067-1070.

8 ）鈴木隆雄, 杉浦美穂, 古名丈人 ·他：地域高齢者の転倒発 生に関連する身体的要因の分析的研究：5年間の追跡研究 から. 日老医誌, 1999，36(7)：472-478.

9 ) Prudham D, Evans JG.: Factors associated with falls in the elderly: a community study. Age Ageing, 1981, 10(3): 141146.

10) Campbell AJ, Reinken J, Allan BC, et al.: Falls in old age: a study of frequency and related clinical factors. Age Ageing, 1981, 10(4): 264-270.

11) Blake AJ, Morgan K, Bendall MJ, et al.: Falls by elderly people at home: prevalence and associated factors. Age Ageing, 1988, 17(6): 365-372.

12) Tinetti ME, Speechley M, Ginter SF.: Risk factors for falls among elderly persons living in the community. N Engl J Med, 1988, 319(26): 1701-1707.

13) Downton JH, Andrews K:: Prevalence, characteristics and factors associated with falls among the elderly living at home. Aging (Milano), 1991, 3(3): 219-228.

14) Rubenstein LZ, Josephson KR.: The epidemiology of falls and syncope. Clin Geriatr Med, 2002, 18(2): 141-158.

15) Rubenstein LZ, Robbins AS, Schulman BL, et al.: Falls and instability in the elderly. J Am Geriatr Soc, 1988, 36(3): 266278.

16) Ganz DA, Bao Y, Shekelle PG, et al.: Will my patient fall? JAMA, 2007, 297(1): 77-86. 